Division of Geological \& Geophysical Surveys

PRELIMINARY INTERPRETIVE REPORT 2009-4

\title{
PRELIMINARY EVALUATION OF BASIN MARGIN EXHUMATION AND PROVENANCE OF CENOZOIC STRATA, CHUITNA AND BELUGA RIVERS AREA, COOK INLET FOREARC BASIN, ALASKA
}

\author{
by \\ Emily S. Finzel, Robert J. Gillis, \\ Kenneth A. Ridgway, and David L. LePain \\ June 2009 \\ THIS REPORT HAS NOT BEEN REVIEWED FOR \\ TECHNICAL CONTENT (EXCEPT AS NOTED IN TEXT) OR FOR \\ CONFORMITY TO THE EDITORIAL STANDARDS OF DGGS. \\ Released by \\ STATE OF ALASKA \\ DEPARTMENT OF NATURAL RESOURCES \\ Division of Geological \& Geophysical Surveys \\ 3354 College Rd. \\ Fairbanks, Alaska 99709-3707
}





\section{CONTENTS}

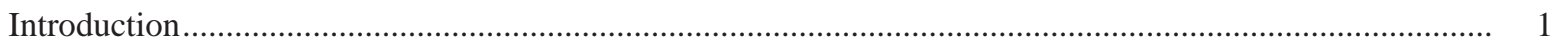

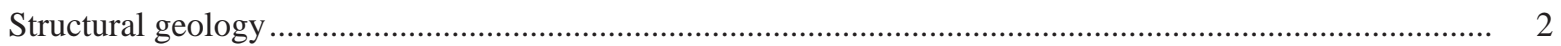

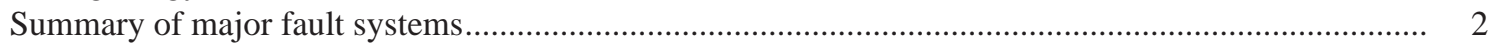

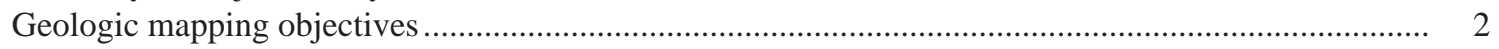

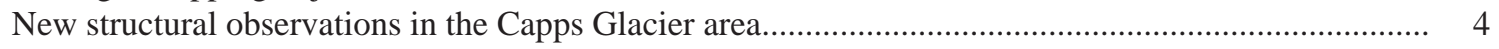

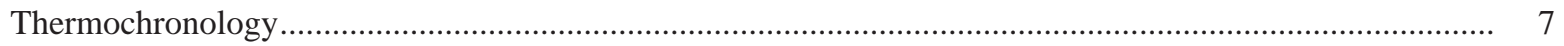

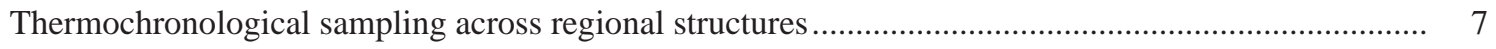

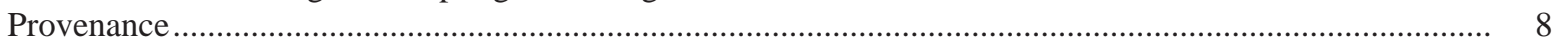

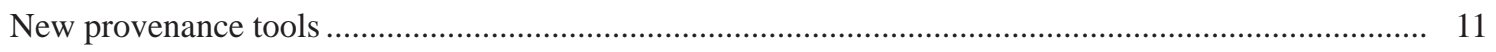

Clast composition of paleogene basin margin conglomerates ....................................................... 11

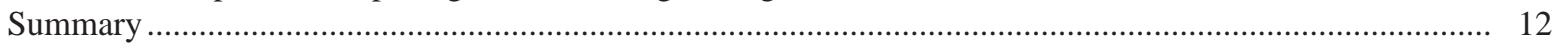

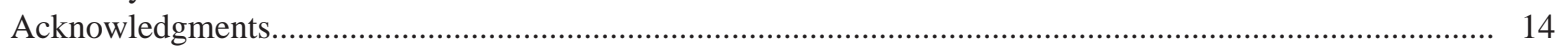

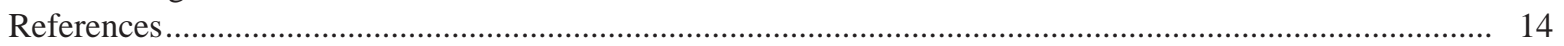

\section{FIGURES}

Figure 1. Map of southern Alaska showing topography, major fault systems, magmatic arcs, and plate motions relative to North America................................................................................... 1

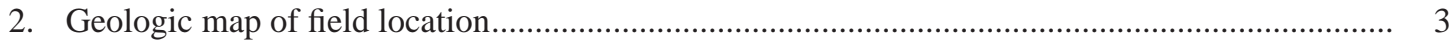

3. View looking to the northeast at the Capps Glacier fault, showing the field relationship between granitic hangingwall rocks and gently-deformed footwall Cenozoic deposits ............................ 3

4. Interpreted aerial photograph of the Capps Glacier area, highlighting map relationships between granitic, Jurassic basement rocks, and Cenozoic basin fill deposits ...

5. View looking west at the high-angle depositional contact between gently southeast-dipping Cenozoic basin fill and highly sheared Jurassic-Cretaceous metavolcanic rock ........................ 6

6. View looking southwest at folded tuffaceous Cenozoic strata obliquely truncated by high-angle

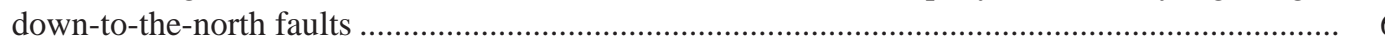

7. Generalized geologic map of the 2007 field study area highlighting sampling locations and clast count locations relative to regional geologic structures....................................................... 8

8. Schematic cross sections along the Chuitna River drainage................................................. 9

9. Closure temperatures of thermochronometers plotted as a function of the rate at which the host rocks are cooled..

10. Conglomerate clast compositions from the Hemlock, West Foreland, and Tyonek Formations from clast counts conducted on outcrops. 



\section{PRELIMINARY EVALUATION OF BASIN MARGIN EXHUMATION AND PROVENANCE OF CENOZOIC STRATA, CHUITNA AND BELUGA RIVERS AREA, COOK INLET FOREARC BASIN, ALASKA}

by

Emily S. Finzel ${ }^{1}$, Robert J. Gillis², Kenneth A. Ridgway' ${ }^{1}$ and David L. LePain ${ }^{2}$

\section{INTRODUCTION}

Southern Alaska is arguably the most tectonically active part of the convergent margin of western North America, with the world's largest exposed accretionary prism, the highest topography in North America, two active volcanic arc complexes, and some of the world's largest strike-slip fault systems (fig. 1; Plafker and Berg, 1994). The Cenozoic Cook Inlet basin, in the forearc region of this convergent system, is bordered on its northwestern margin by the subduction-related Aleutian-Alaska Peninsula magmatic arc (Plafker and Berg, 1994). The Chugach Mountains on the southeastern margin of the basin are composed of sediments scraped off the subducting slab by the overlying plate, and form an accretionary prism that has been building since the Mesozoic and continues to grow today (Kusky and others, 1997).

Exhumation and growth of these first-order tectonic features is directly linked to subsidence and sediment supply in the adjacent sedimentary basin (Dickinson, 1995). In addition, contractional processes in basins cause crustal thickening with the development of thrust and reverse faults, which lead to localized loads and isostatic subsidence, as well as increased sediment supply. Examining the structural configuration and sedimentary record can help us understand the timing and kinematics of basin development, which in turn lead to a more comprehensive model for depositional and hydrocarbon systems within the basin.

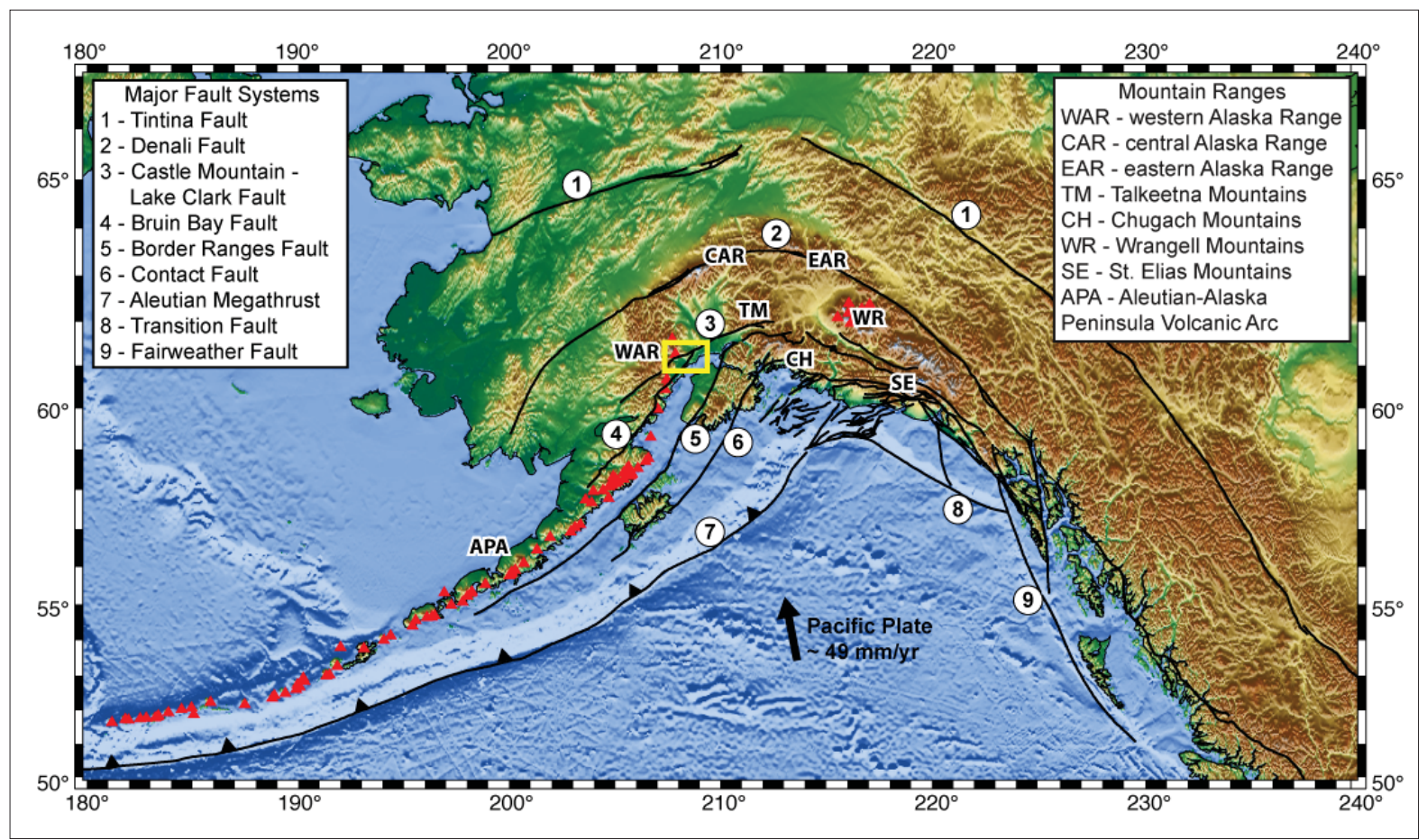

Figure 1. Map of southern Alaska showing topography, major fault systems, magmatic arcs, and plate motions relative to North America. The yellow box outlines the study area shown in detail in figure 2.

${ }^{1}$ Department of Earth and Atmospheric Sciences, Purdue University, West Lafayette, Indiana 47907; Emily Finzel: efinzel@purdue.edu ${ }^{2}$ Alaska Division of Geological \& Geophysical Surveys (DGGS), 3354 College Road, Fairbanks, Alaska 99709 
The purpose of this paper is to report briefly on ongoing structural, thermochronologic, and stratigraphic investigations along the northwestern margin of Cook Inlet basin. Recent reconnaissance mapping, particularly near the Capps Glacier fault, has provided new constraints on the structural style of basin-bounding faults. New high- and low-temperature thermochronologic samples were collected adjacent to regional faults; future analytical results from these samples will help to provide constraints on timing and rates of cooling across fault boundaries. In addition, provenance data collected from conglomeratic strata adjacent to major faults allows us to identify the stratigraphic units exposed at the surface during deposition of the conglomerate. Although still preliminary, these data sets offer complementary constraints, which when considered in the context of basin stratigraphy, paleoflow, and sediment provenance, are expected to establish links between fault motion, sediment source area exhumation, and adjacent basin sedimentation. A better understanding of the Cenozoic tectonic controls will facilitate more accurate and detailed depositional models for Cook Inlet basin.

\section{STRUCTURAL GEOLOGY}

\section{SUMMARY OF MAJOR FAULT SYSTEMS}

Several major fault systems may have been active during formation of the Cenozoic forearc basin, and some continue to accommodate deformation today (Plafker and Berg, 1994). In the Chuitna-Beluga River region, the Castle Mountain, Lake Clark, and Bruin Bay faults form the northern and northwestern margins of Cook Inlet basin (figs. 1 and 2). These reverse faults are located over a northwest-side-up step in the Mesozoic basement and display similar northwest-side-up displacement with some component of oblique slip (Haeussler and others, 2000). The Castle Mountain and Lake Clark faults lie along strike to one another and may be related at depth (Detterman and others, 1976).

Of these three fault systems, only the Castle Mountain fault is inferred to have Holocene motion based on fault scarps and historical seismicity (Haeussler and others, 2000). Grantz (1966) and Fuchs (1980) suggest motion on the eastern part of the fault since at least Early Cenozoic time with up to $1.2 \mathrm{~km}$ of reverse motion (Barnes and Payne, 1956) and as much as $130 \mathrm{~km}$ of right lateral separation (Trop and others, 2005). On the western segment of the fault, an offset postglacial outwash channel yields a slip rate of $2.8-3.0 \mathrm{~mm} / \mathrm{yr}$ for the last 13,000 years (Willis and others, 2007). In the study area, this fault dips steeply to the north and juxtaposes lower Eocene West Foreland or Oligocene Hemlock Formation against lower Miocene Tyonek Formation (fig. 2; Detterman and others, 1976; Magoon and others, 1976).

The Lake Clark fault system is estimated to have $500-1,000 \mathrm{~m}$ of vertical offset based on stratigraphic relationships; however, the timing of deformation on this fault system is unclear (Detterman and others, 1976). Some evidence suggests approximately $5 \mathrm{~km}$ to as much as $26 \mathrm{~km}$ of right lateral motion since late Eocene time, but before Quaternary time (Plafker and others, 1975; Ivanhoe, 1962; Haeussler and Saltus, 2005). Other studies indicate evidence for Pleistocene, but not Holocene, deformation on the fault based on offset glacial moraines (Schmoll and Yehle, 1987). In the Chuitna-Beluga area, this fault places lower Eocene West Foreland Formation over upper Miocene Beluga Formation (fig. 2; Magoon and others, 1976).

The Bruin Bay fault system has had perhaps the most long-term control on sedimentation in the Cook Inlet and Alaska Peninsula regions of all the major tectonic elements bounding the western and northern margins of Cook Inlet basin. Along the lower Cook Inlet basin, left-lateral separation that is estimated at 19 to $65 \mathrm{~km}$ and vertical stratigraphic separation in excess of $3 \mathrm{~km}$ may decrease northeastward along the fault to perhaps only a few hundred meters near the Castle Mountain fault (Detterman and Hartsock, 1966; Detterman and Reed, 1980). New apatite fission-track data from the Katmai National Park area suggests that from 2 to $4.5 \mathrm{~km}$ of exhumation of the upthrown (northwestern) block has occurred since Late Paleocene time (Gillis and others, 2008). Significant regional motion along the Bruin Bay fault may have ceased by Late Oligocene time in the Katmai area based on the cross-cutting relationship of an apparently underformed igneous body (Detterman and Reed, 1980; Detterman and others, 1996). However, in upper Cook Inlet, deformed strata in the downthrown (southeastern) side of the Bruin Bay fault may indicate Quaternary motion (Bruhn and Haeussler, 2006). In the study area, the Bruin Bay fault is represented by a broad zone of deformation that places lower Miocene Tyonek Formation over upper Miocene Beluga Formation along the Chuitna and Beluga rivers (fig. 2; Magoon and others, 1976).

\section{GEOLOGIC MAPPING OBJECTIVES}

To gain a better understanding of the structural geology of the northwestern margin of upper Cook Inlet basin, goals through 2009 include new 1:63,360-scale mapping of an approximately 4,300 $\mathrm{km}^{2}$ area centered upon Tertiary outcrops along the Beluga and Chuitna rivers (fig. 2). The proposed map area encompasses exposures or inferred 


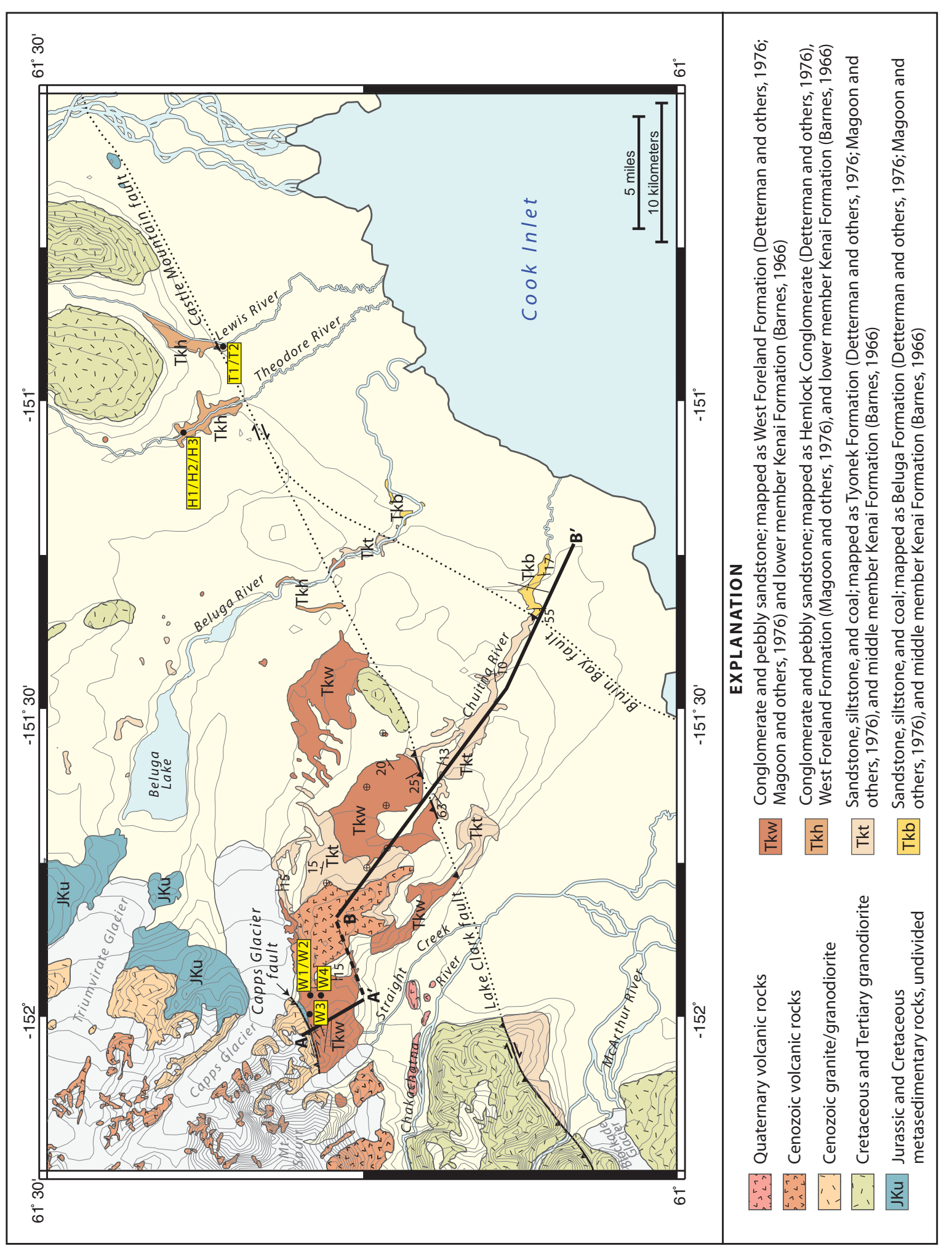

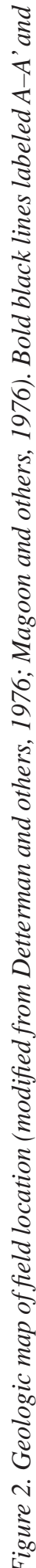


locations of the Castle Mountain, Bruin Bay, Lake Clark, and Capps Glacier faults. Throughout the mapping effort, special attention will be paid to fold geometries and orientations, fault cut-off relationships, outcrop-scale structural orientations, and kinematic slip indicators where observed, to develop a viable geometric and kinematic understanding of the map area. Geologic mapping results will help direct future thermochronologic sampling and analyses and provide a structural framework within which to interpret the new cooling data. Together with basin analyses of adjacent Cenozoic sedimentary exposures, we hope to construct a kinematic model highlighting the Cenozoic tectonic evolution of the region.

\section{NEW STRUCTURAL OBSERVATIONS IN THE CAPPS GLACIER AREA}

Structural efforts in the summer of 2007 focused on reconnaissance field studies in the Capps Glacier area approximately $15 \mathrm{~km}$ northwest of the Lake Clark fault (fig. 2). This area is a key location for understanding Cook Inlet basin margin relationships because well-exposed, gently-deformed Cenozoic strata are not only in clear fault contact with Cenozoic granite along the Capps Glacier fault, but unconformably overlie Jurassic and Cretaceous metamorphic basement rocks as well (figs. 3 and 4). Readily visible geologic structures occurring within the Cenozoic interval near Capps Glacier may provide an analog for the structural style of more poorly exposed strata deformed by the Lake Clark, Bruin Bay, and Castle Mountain faults to the southeast. The potential for syntectonic sedimentation adjacent to the fault and local abundance of folded and undeformed dateable tuffaceous beds holds promise for placing constraints on the timing of deformation associated with motion along the fault.

The Capps Glacier fault is exposed along a short, approximately $4 \mathrm{~km}$, interval $15 \mathrm{~km}$ northwest of the Lake Clark fault, between Straight Creek to the southwest and Capps Glacier to the northeast (Gillis and others, 2009) (figs. 2 and 4). Although outcrop exposures are generally excellent in this area, little is known about the nature of the Capps Glacier fault or geologic structures in the Cenozoic sedimentary rocks exposed immediately to the southeast. The only original geologic mapping published for this area was is reconnaissance mapping by Barnes (1966), which was later incorporated into a more widely distributed geologic map compiled by Magoon and others (1976). Barnes (1966) interpreted the Capps Glacier fault as a reverse fault with possible normal reactivation. Interpretation of the principal sense of motion was based upon a younger-over-older fault relationship along a steeply northwest-dipping surface. Here, late Paleocene granite (Reed and Lanphere, 1969) to the northwest is juxtaposed against gently deformed early Cenozoic strata (Barnes, 1966; Wolfe and others, 1966; Adkison and others, 1975), and locally highly deformed Cretaceous-Jurassic metavolcanic rock. Two east-west-striking, downto-the-north normal faults mapped by Barnes (1966) deform the Cenozoic strata and are separated from the Capps Glacier fault by an open anticline. The map relationship indicates the northern limb of the anticline is truncated

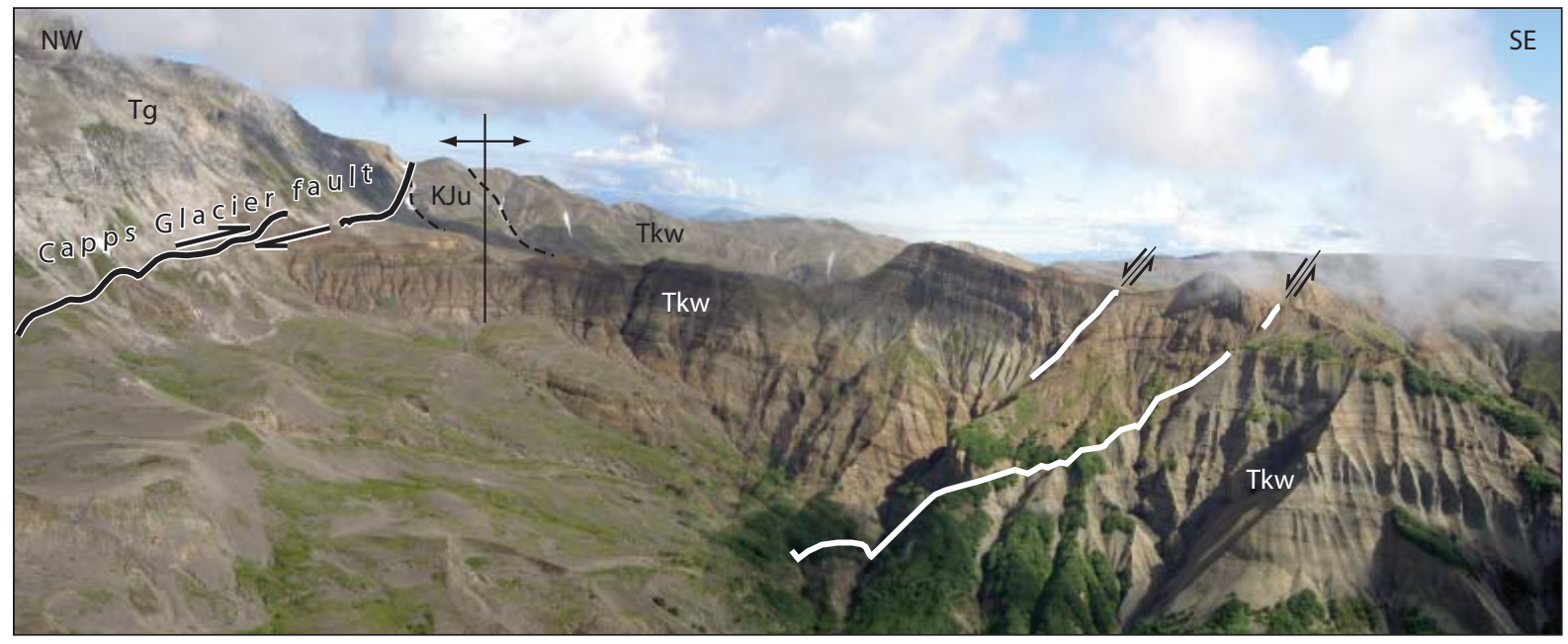

Figure 3. View looking to the northeast at the Capps Glacier fault, showing the field relationship between granitic hangingwall rocks (Tg) and gently-deformed footwall Cenozoic deposits in the foreground (Tkw). A narrow strip of Jurassic and Cretaceous basement rocks $(\mathrm{KJ} u$ ) on the horizon stratigraphically underlie the Tkw and are locally juxtaposed against granitic rocks along the fault ( $\mathrm{Tg}$ ). 


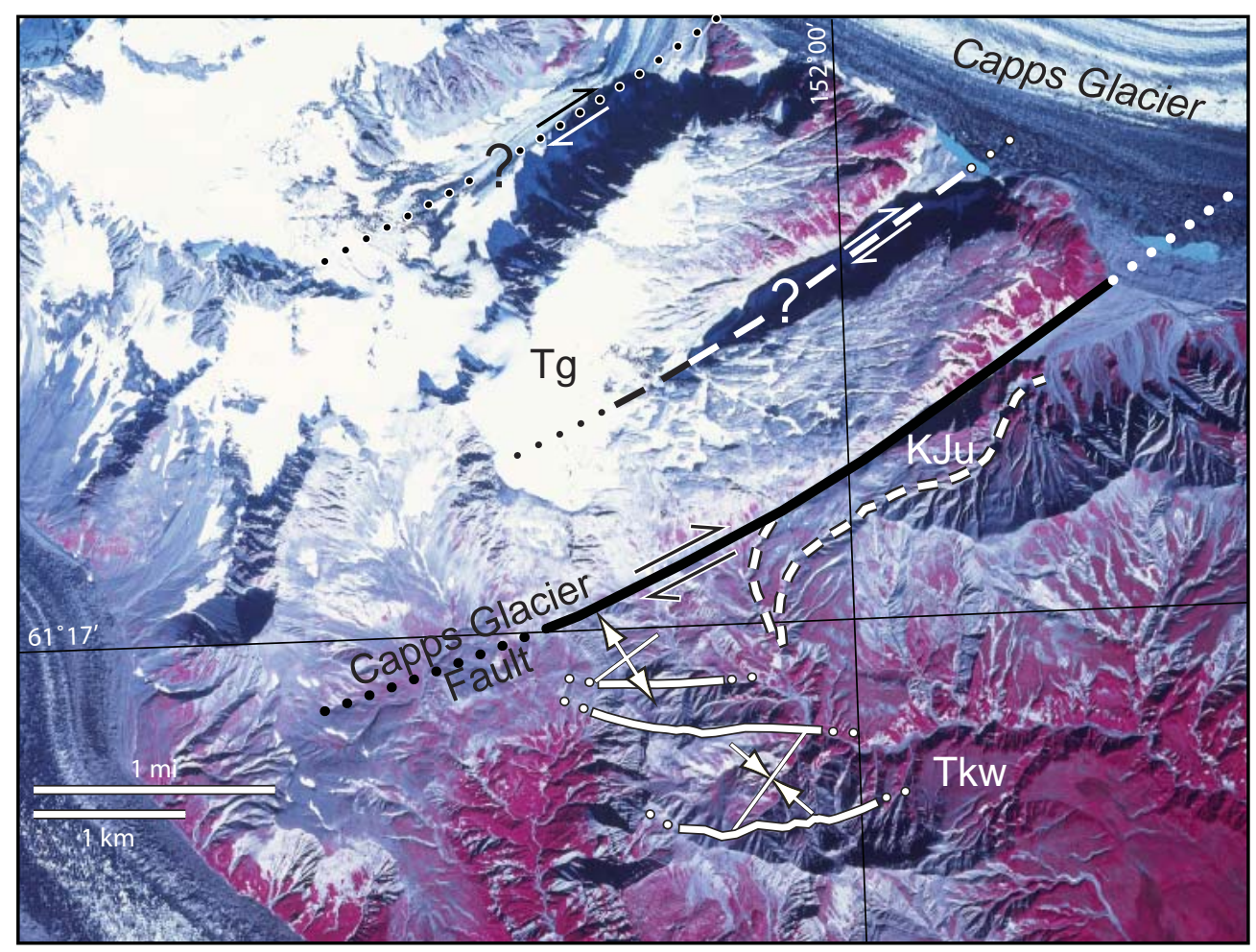

Figure 4. Interpreted aerial photograph of the Capps Glacier area, highlighting map relationships between granitic (Tg), Jurassic basement rocks (KJu) and Cenozoic basin fill deposits (Tkw). The near-linear trace of the Capps Glacier fault indicates a very steep northwestern dip of the fault plane. Folds within the Cenozoic deposits are oriented obliquely to the trace of the Capps Glacier fault and are truncated by intrabasinal faults discussed in text.

against the Capps Glacier fault and is interpreted to represent extensional drag folding of the Cenozoic strata during normal reactivation of the fault.

Reconnaissance investigation of the Capps Glacier area in the summer of 2007 by DGGS geologists confirms the basic locations and orientations of the structures mapped by Barnes (1966). However, the more recent work also identified new structures and geologic relationships within the Cenozoic basin deposits, along with a better understanding of the sense of motion along the Capps Glacier fault. Good outcrop exposure, often to within a few meters of the Capps Glacier fault, allows for clear identification of hangingwall and footwall relationships. The near-linear trace of the fault as it intersects topography suggests a steeply northwest-dipping surface (fig. 4). Along much of the length of the Capps Glacier fault, Cenozoic granite to the northwest is juxtaposed against Cenozoic basin deposits to the southeast (figs. 2 and 4). Hangingwall granitic rock in fault contact with highly sheared Cretaceous-Jurassic footwall greenstone occur along the northeastern segment of the fault where the Cenozoic strata in the footwall of the Capps Glacier fault unconformably overlies the metamorphic basement rocks (figs. 2, 4, and 5). The younger-over-older relationship implies either dip-slip reverse motion along a high-angle structure as initially suggested by Barnes (1966), or oblique-slip motion along a transpressional structure. Limited slip lineations measured from subsidiary shear planes within the granite indicate that it may be the latter, with surface grooves and mineral fibers oriented at less than $30^{\circ}$ to horizontal (Gillis and others, 2009). Footwall strata also exhibit minor folding and faulting possibly related to separate generations of deformation. (figs. 4 and 5).

Cenozoic basinal strata to the southeast of the Capps Glacier fault generally exhibit a homoclinal dip of about $15^{\circ}$ to the southeast. However, small-scale folds and faults deform the Cenozoic basin fill southwest of a mostly east-trending drainage bisecting the basin exposure (figs. 2, 4 and 6). Faults southwest of the drainage strike approximately east-west with steep northward dips and apparent down-to-the-north separation. Apparent drag folding in hangingwall and footwall strata suggest extensional or transtensional motion along the faults (fig. 2). The magnitude of displacement along the faults is unclear, but appears to range from tens of meters to perhaps 


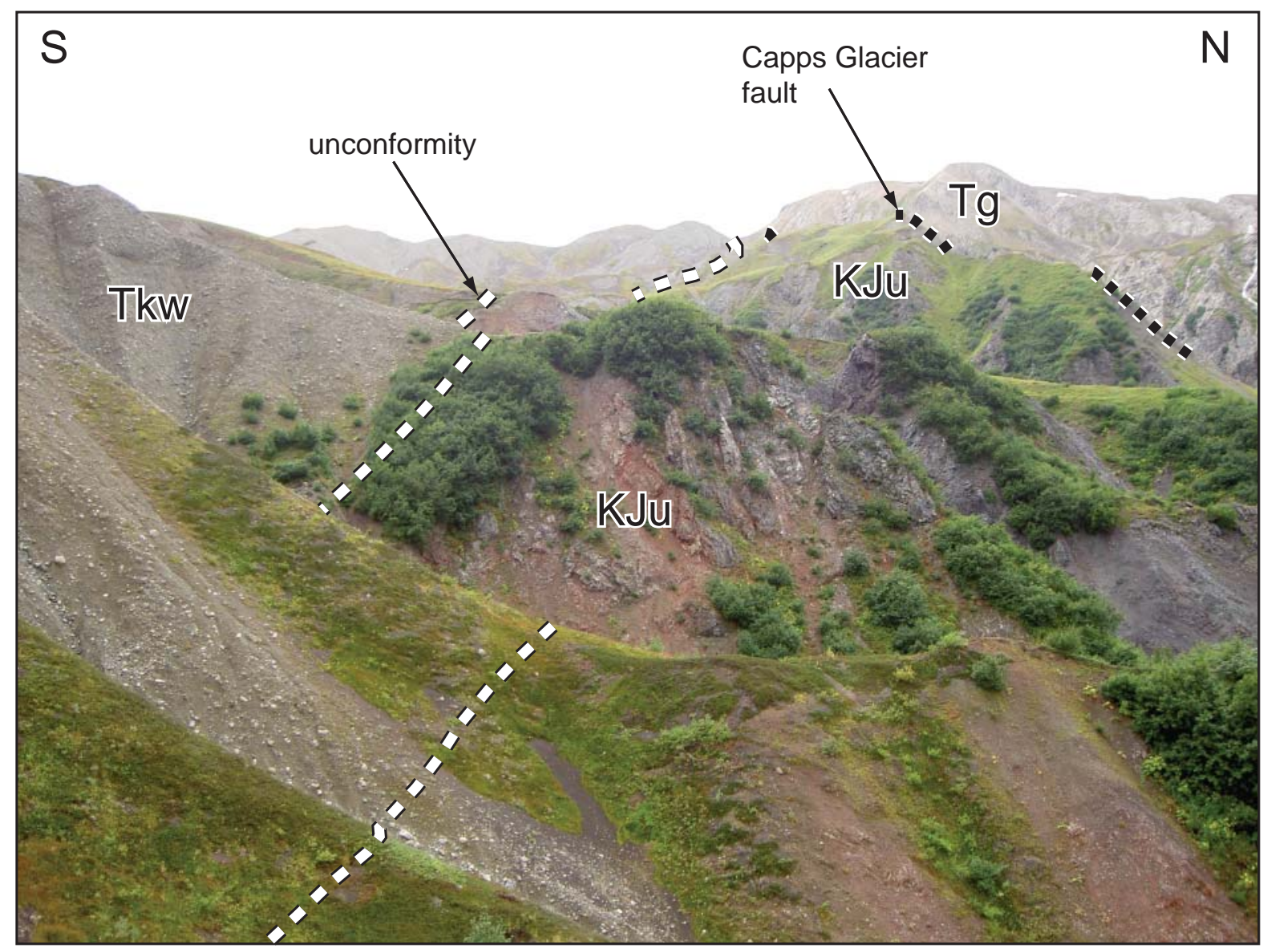

Figure 5. View looking west at the high-angle depositional contact between gently southeast-dipping Cenozoic basin fill (Tkw) and highly sheared Jurassic-Cretaceous metavolcanic rock (KJu). The fault contact between granitic ( $\mathrm{Tg}$ ) and Jurassic basement rocks (KJu) along the Capps Glacier fault appears in the background.

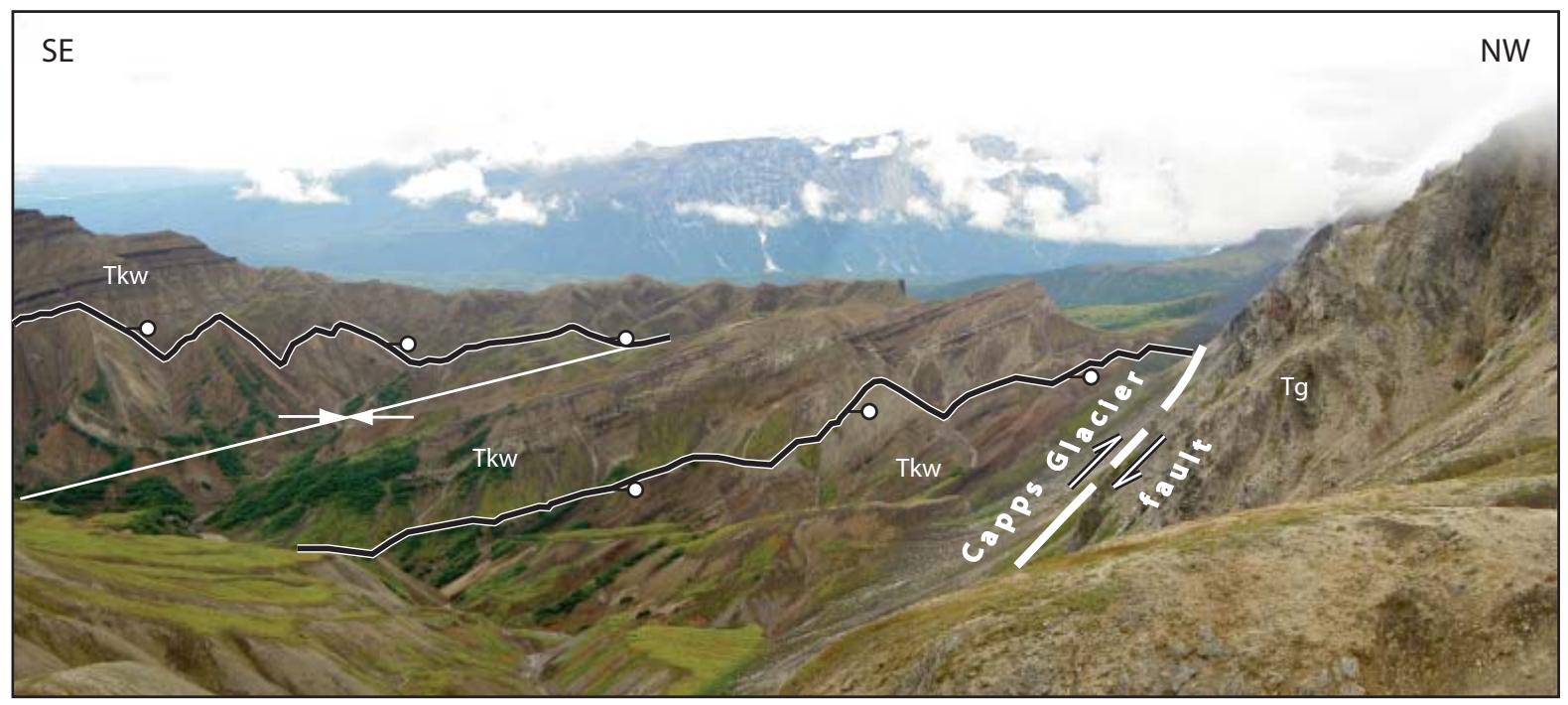

Figure 6. View looking southwest at folded tuffaceous Cenozoic strata (Tkw) obliquely truncated by high-angle down-to-the-north faults. 
several hundred based on distinct facies differences in hangingwall and footwall strata across two of the more prominent faults. Adkison and others (1975) estimate up to 1,000 $\mathrm{m}$ of down-to-the-north throw has been accommodated by one of these faults, and speculate that similar faults may continue into exposures approximately $6 \mathrm{~km}$ to the east. Both the observed and inferred faults either trend into, or approximately correspond with, the east-west drainage bisecting the basin exposure, suggesting that the location and orientation of the drainage may be structurally controlled.

Open folds within the Cenozoic basin deposits are oriented obliquely to both the Capps Glacier and local intrabasinal faults. Fold axes are rotated approximately $20^{\circ}$ to $30^{\circ}$ counterclockwise to the trace of the Capps Glacier fault and approximately $45^{\circ}$ to the traces of intrabasinal faults (fig. 4) based on preliminary field mapping and aerial photograph interpretation. Bruhn and Haeussler (2006) note similar oblique orientations of fault-cored anticlines in Cook Inlet basin with respect to the transpressional Bruin Bay and Castle Mountain faults, possibly implying that the Capps Glacier fault and associated folds evolved within a similar regional stress regime.

The laterally discontinuous folds are obliquely truncated by the intrabasinal faults, recording either concurrent folding or faulting, or more likely two separate phases of deformation of the Cenozoic section. This relationship is particularly evident along the moderately northwest-dipping limb of a prominent syncline that has been clearly truncated at a high, oblique angle against gently southeast-dipping strata of notably different lithology (fig. 6). It is plausible that local later-stage extension could be related to the development of an apparent right-stepping releasing bend in the dextral Lake Clark fault approximately $17 \mathrm{~km}$ to the south of the Capps Glacier fault. Thus, identifying and constraining the timing of different phases of local deformation could have implications for the kinematic development of regional structures along the western margin of Cook Inlet basin. To that end, radiogenic age dates from tuffaceous beds folded within the prominent syncline near the Capps Glacier fault should provide a maximum age of deformation of the basin deposits. If deposition within the basin was syntectonic and stratal thickening can be documented within the syncline core during field operations in the summer of 2008, it may be possible to constrain the timing of local syn- and post-depositional deformation.

\section{THERMOCHRONOLOGY}

Cooling ages of minerals brought to the Earth's surface via tectonic or erosional processes have been instrumental for recognizing episodes of rapid exhumation in a variety of tectonic settings (Fitzgerald and others, 1995; Ehlers and others, 2003; Spotila and others, 2007). Comprehensive cooling histories of samples, sometimes reflecting multiple episodes of exhumation, can be established by employing several thermochronometers representing a wide temperature range (for example, Kirby and others, 2002; Gillis and others, 2006; Guest and others, 2006). When comprehensive cooling histories are considered within the framework of the regional geologic structures and basin sedimentation, a kinematic tectonic history of the region is achievable (for example, Bullen and others, 2001; Guest and others, 2006).

\section{THERMOCHRONOLOGIC SAMPLING ACROSS REGIONAL STRUCTURES}

During the 2007 field season, 30 samples were collected by DGGS for 51 thermochronologic analyses from granitic, metavolcanic basement, and Cenozoic basin-fill rocks in the Tyonek area of upper Cook Inlet basin. Sampling was conducted in the upthrown and downthrown blocks of the Castle Mountain, Bruin Bay, Lake Clark, and Capps Glacier faults to identify potential exhumation-induced differential cooling across regional structures (figs. 7 and 8). Samples from the Cenozoic basin fill were concentrated primarily along discontinuous exposures along the Chuitna and Beluga river drainages. In the upthrown and downthrown blocks of the Lake Clark fault near Blockade Glacier, and the upthrown blocks of the Capps Glacier fault and Castle Mountain fault near Mt. Susitna, granitic samples were collected over vertical intervals near the fault contacts for more detailed cooling information (fig. 3).

Six granitic samples have been high-graded for 14 analyses including ${ }^{40} \mathrm{Ar} /{ }^{39} \mathrm{Ar}$ dating of hornblende, biotite, and potassium feldspar; and apatite fission-track methods for their wide range of closure temperatures and collective ability to produce detailed cooling histories from emplacement temperatures to approximately $60^{\circ} \mathrm{C}$.

${ }^{40} \mathrm{Ar} /{ }^{39} \mathrm{Ar}$ analyses of hornblende will provide a baseline for constructing cooling histories for individual samples by establishing improved minimum intrusive ages for magmatic bodies previously dated by Reed and Lanphere (1969) using the older and less reliable K-Ar method. Potassium feldspar analyses with well-behaved ${ }^{40} \mathrm{Ar} /{ }^{39} \mathrm{Ar}$ systematics can record continuous cooling information from approximately $350^{\circ}$ to $150^{\circ} \mathrm{C}$ (Lovera and others, 1989), and will bridge a gap between cooling ages of common high- and low-temperature thermochronometers (fig. 9). Inverse modeling of apatite fission-track data can also produce continuous cooling information from ap- 


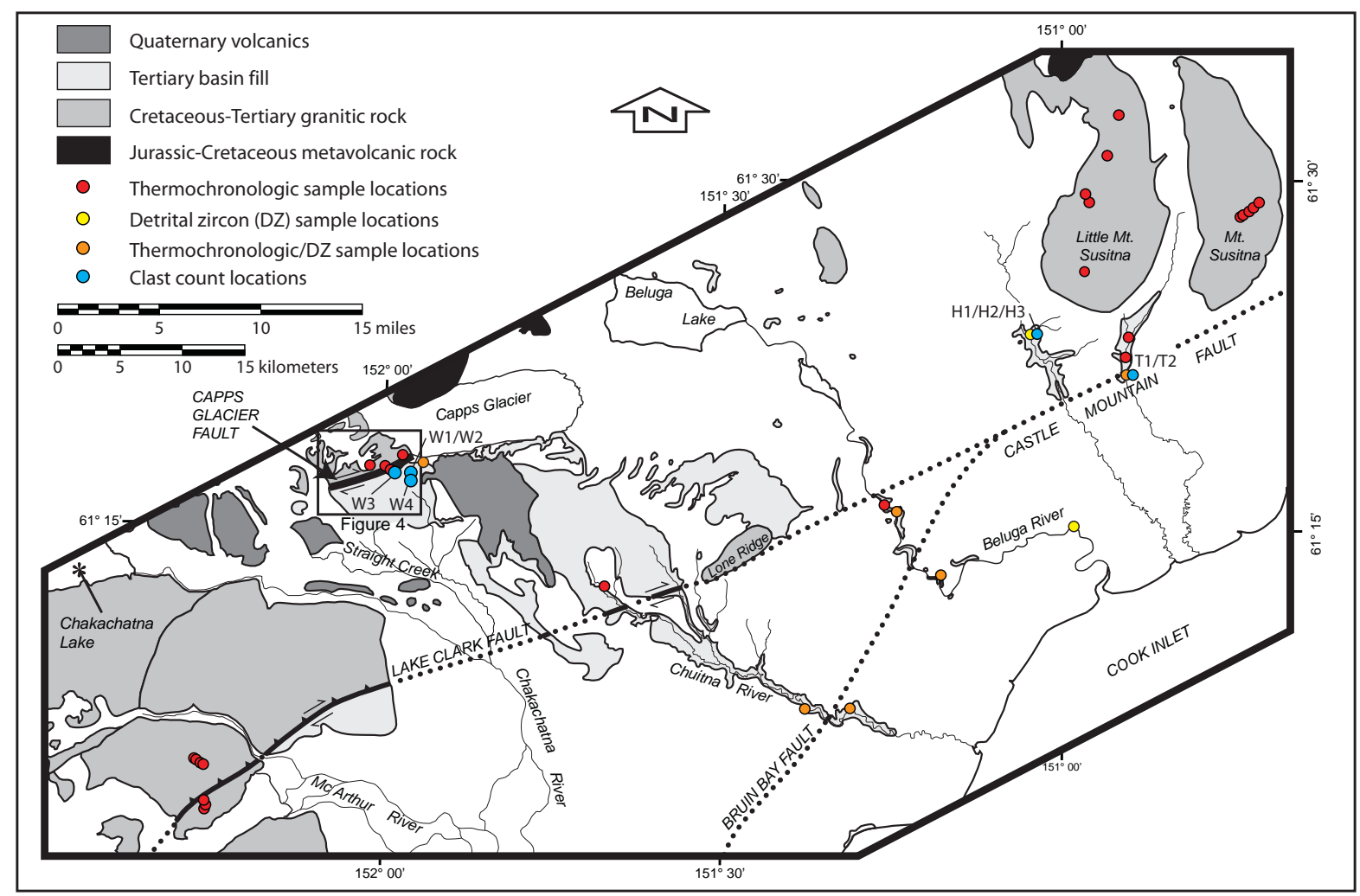

Figure 7. Generalized geologic map of the 2007 field study area highlighting thermochronologic (red circles), detrital zircon (yellow circles), and thermochronologic/detrital zircon (orange circles) sampling locations, and clast count locations (blue circles) relative to regional geologic structures.

proximately $110^{\circ}$ to $60^{\circ} \mathrm{C}$ (Ketcham and others, 2000), and when integrated with hornblende, biotite, and potassium feldspar cooling data, can render a well-defined composite cooling history of granitic samples from emplacement to exhumation within a few kilometers of the earth's surface (fig. 9).

It is uncertain if four samples collected from Cenozoic basin deposits along a transect following the Chuitna River were buried deeply enough to completely reset low-temperature detrital thermochronometers. Therefore, vitrinite reflectance analyses of nearby samples are in progress to estimate the depth of burial of the deposits. The samples will be analyzed using apatite fission-track or the lower temperature apatite (U-Th)/He methods (approximately $70^{\circ} \mathrm{C}$ ) (Farley, 2000) as depth of burial permits. If it is determined that burial depth was too shallow to completely reset either thermochronometer, then detrital apatite fission-track analyses of the four Tertiary basin fill samples will be conducted to provide additional constraints on depositional ages and augment sediment provenance investigations outlined below.

In summary, forthcoming thermochronologic results from opposite sides of the Capps Glacier, Lake Clark, Bruin Bay, and Castle Mountain faults will be instrumental in establishing detailed cooling histories of rocks along regional basin-controlling structures, perhaps highlighting episodes of relative cooling between individual fault blocks. These data will be compared with collaborative basin analyses of adjacent Cenozoic units in an attempt to kinematically link source-area exhumation with proximal depocenter sedimentation.

\section{PROVENANCE}

Previous studies have proposed that the Cenozoic depositional systems in Cook Inlet basin consisted of basin margin alluvial fans and an axial fluvial system that drained south into the Pacific (Kirschner, 1988; Swenson, 1997). These systems were fed by distinct source terranes, including the adjacent Mesozoic-Cenozoic volcanic arc to the west and subduction complex to the east, as well as far-field sources like the central Alaska Range and western Yukon Territory. The extent and location of these depositional systems were controlled by local and regional exhumation and sediment input (Flores and others, 2004). 

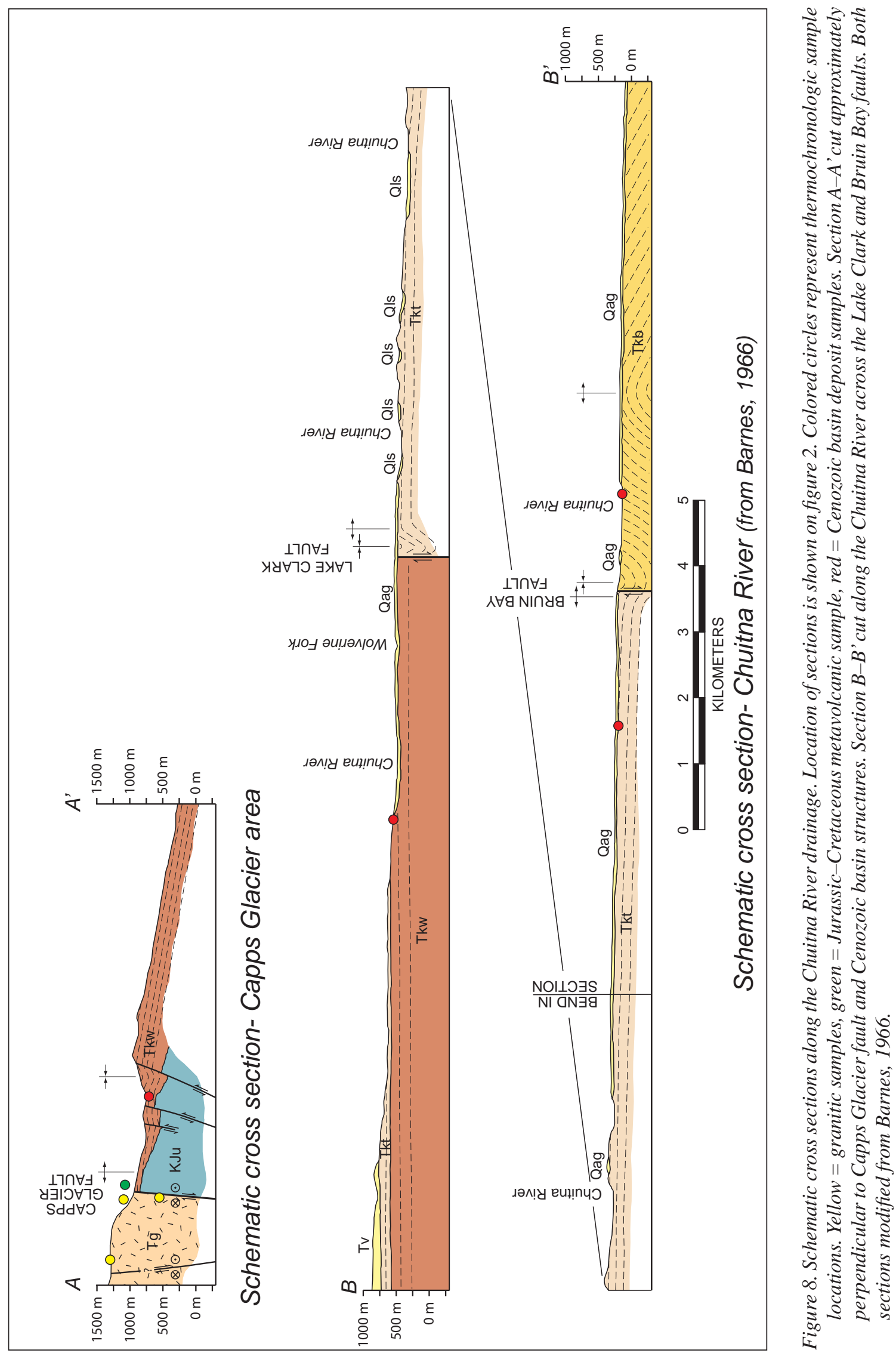

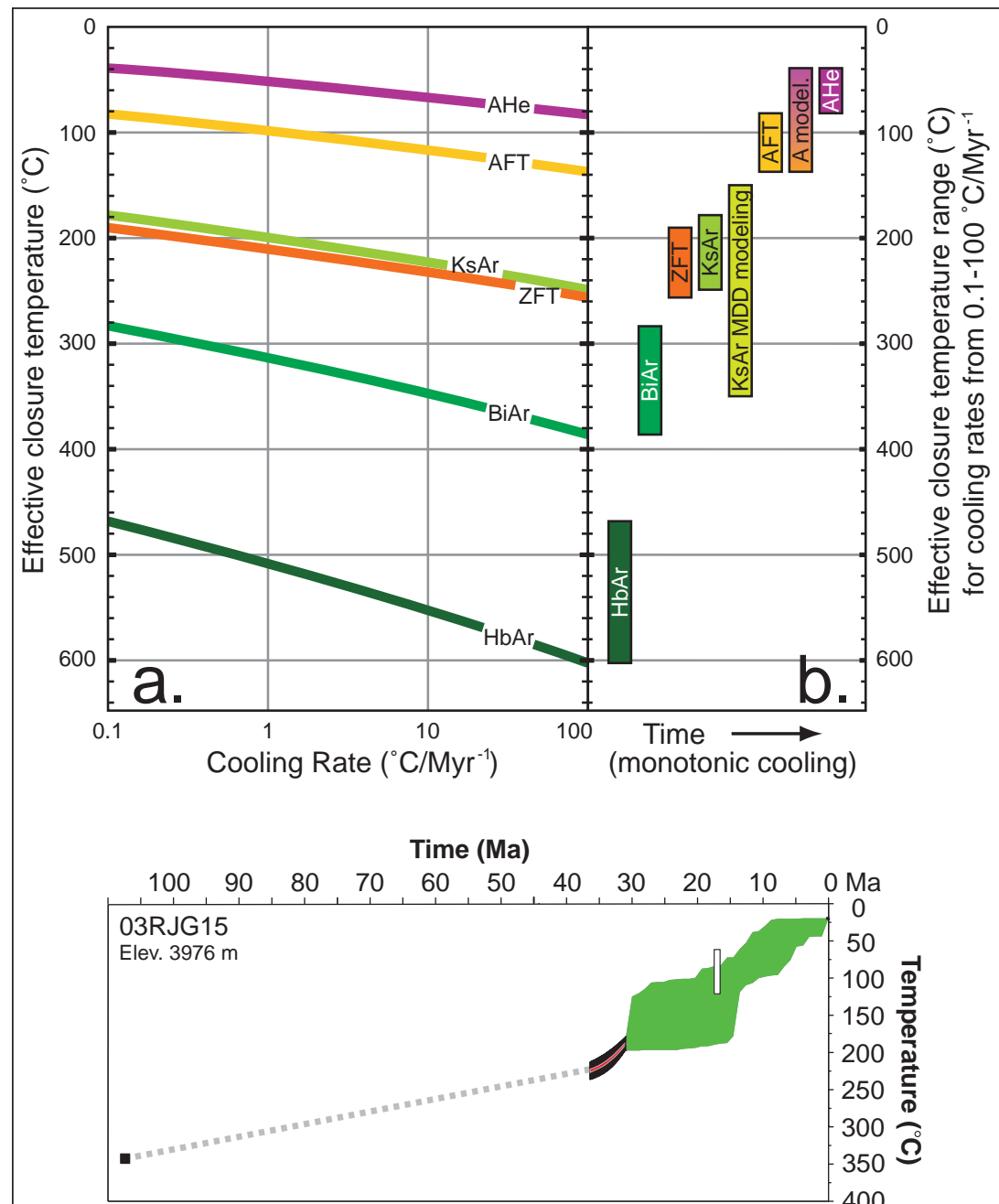

Thermal modeling

Potassium feldspar (MDD)

- 90\% confidence limit of overall distribution

$\square 90 \%$ confidence limit of median

Apatite fission track $\square$ Acceptable fit

$\square$ Good fit

Thermochronometer closure temp.

- Muscovite ${ }^{40} \mathrm{Ar} /{ }^{39} \mathrm{Ar}$ wt. mean age

Biotite ${ }^{40} \mathrm{Ar} /{ }^{39} \mathrm{Ar}$ wt. mean age

$\square$ AFT pooled age
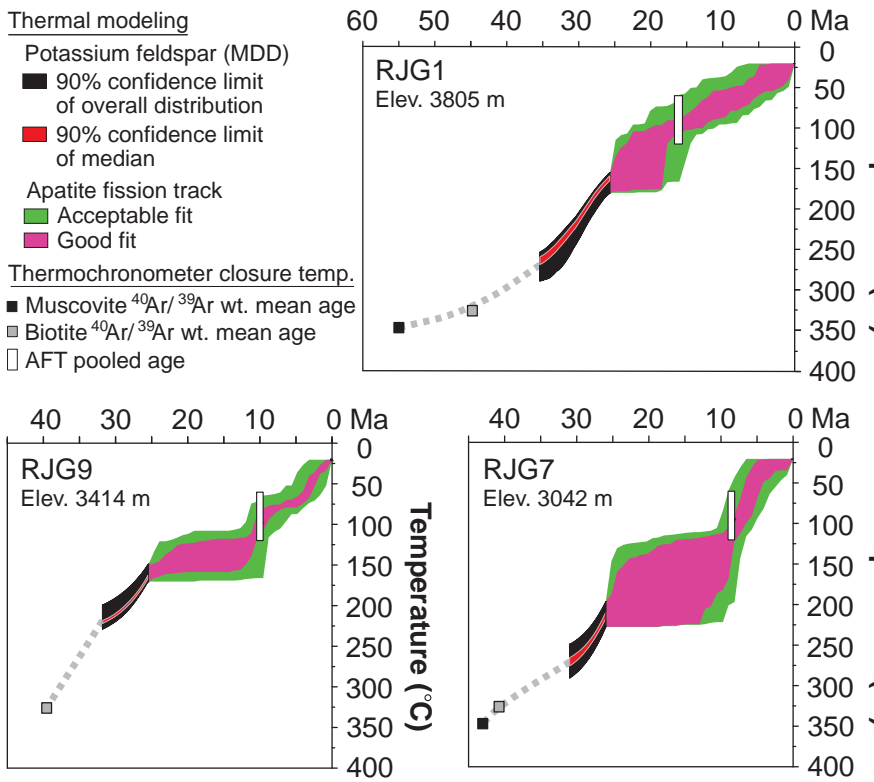

C.
Figure 9. (a) Closure temperatures of thermochronometers plotted as a function of the rate at which the host rocks are cooled (adapted from Reiners and Brandon, 2006). AHe $=$ apatite $(U-T h) / H e, A F T=$ apatite fission track, $\mathrm{KsAr}=$ potassium feldspar Ar/Ar, ZFT = zircon fission track, $B i A r=$ biotite $A r / A r$, and $\mathrm{HbAr}=$ hornblende Ar/Ar. (b) Effective closure temperature range extrapolated from (a) illustrating the utility of employing multiple thermochronometers to construct comprehensive cooling histories of exhumed rocks. KsAr MDD modeling = nominal temperature range of potassium feldspar Ar/Ar multiple diffusion domain modeling, and A model. = temperature range of apatite fission track-(U-Th)/He multi-kinetic modeling. (c) Examples of composite cooling histories constructed for granitic samples showing changes in cooling rate with time and multiple episodes of rapid exhumation-induced cooling (Gillis and others, 2006). 
To date, broad generalizations about the provenance of the Cook Inlet Cenozoic formations have been made based on petrographic analyses of sandstone and heavy minerals (Hayes and others, 1976; Hite, 1976; Rawlinson, 1984; Magoon and Egbert, 1986; Hickey and others, 2007). Additional needed insight, however, can be gained about sediment provenance, including sediment sorting and recycling, type of source terrane, degree of source terrane weathering, as well as constraints on timing and temporal distribution of distinct sources, by integrating petrographic and geochemical techniques. This is important not only for understanding the controls on the depositional systems, but also because understanding the type and distribution of alluvial and fluvial systems in Cook Inlet basin is essential for efficient hydrocarbon exploration and development.

\section{NEW PROVENANCE TOOLS}

Compositional analysis using sandstone petrography is a well-established tool used to interpret the tectonic history of sediments within a basin (Dickinson and Suczek, 1979; Dickinson and others, 1983; Ingersoll and Suczek, 1979). Results from such analyses aid in the interpretation of uplift, subsidence, and sediment input from surrounding source terranes. Geochemical and isotopic methods, in contrast, have been underutilized until just recently, and the combination of sandstone petrography and geochemical analyses in basin provenance has been applied even less frequently. Geochemical approaches provide many advantages over traditional petrographic approaches, including their general applicability to coarse- and fine-grained strata and mineralogically altered rocks by using the appropriate chemical systems (McLennan and others, 1993; Fildani and Hessler, 2005). Geochemical tools also have the ability to detect minor components and geochemical signatures that would not be recognized petrographically, and the potential to constrain provenance through radiogenic dating methods.

For many years, rare-earth elements (REE) in mudstones have been recognized as useful measures of provenance (McLennan and others, 1993; Fildani and Hessler, 2005; Potter and others, 2005). The key provenance parameters that are extracted from these analyses are REE patterns and the ratio of light to heavy REE (Fildani and Hessler, 2005; Potter and others, 2005). REE patterns are widely used for provenance characterization, and the ratio of light to heavy REE can provide insight into the differentiation of various igneous sources (Potter and others, 2005). REE geochemistry is especially valuable because the majority of sediments on Earth are mudstones.

Detrital geochronology is an instrumental tool for determining provenance in sedimentary basins that in turn can be used to constrain models for basin development and geodynamics. Zircons are present in most sandy sediments, are incredibly resilient through very high temperatures, and may remain a closed system for many depositional cycles. Therefore, ages resulting from U-Pb dating of zircons reflect the time of crystallization for the zircon while forming in the source terrane, or several ages for one crystal could indicate a complicated tectonic history with multiple cycles of metamorphism and related zircon growth.

During the 2006-2008 field seasons, we collected mudstones from select Cenozoic formations for geochemical analyses, and performed clast composition counts on conglomeratic units in the study area. In addition, from each Cenozoic unit exposed in the study area we collected several sandstone samples for petrographic and U-Pb detrital zircon analyses. We anticipate receiving results from all 2009 analyses. Detrital zircon ages and rare-earthelement signatures will be compared to published data obtained from key sediment source areas including the Aleutian-Alaska Peninsula volcanic arc, the Alaska Range, the Talkeetna volcanic arc, and the Chugach Mountains (accretionary prism), in an effort to determine the provenance for each formation. In addition to published igneous ages, we sampled two modern rivers for detrital zircons. The Beluga River drainage area is sourced by the magmatic arc complex directly west of Cook Inlet and should reflect proximal source terranes. The Susitna River's drainage area extends north to include parts of the Alaska Range and should reflect a distal extrabasinal sediment source. These two samples can be used as controls when compared to samples from the ancient strata. Results from these types of studies should allow for a more detailed reconstruction of the Cenozoic depositional systems.

The application of four different tools, clast counts from conglomeratic strata, sandstone petrography, U-Pb isotopes in detrital zircons, and mudstone geochemistry to determine provenance in Cook Inlet basin will help us accomplish our two primary goals. First, we can construct new, more detailed models for the Cenozoic depositional environments in Cook Inlet basin. Second, examination of the temporal and geographic changes in the depositional systems will allow us to make inferences about the geodynamics of basin development, specifically about the controls and mechanisms of change that caused variations in the Cenozoic stratigraphy.

\section{CLAST COMPOSITION OF PALEOGENE BASIN MARGIN CONGLOMERATES}

New compositional data were collected from Eocene-Miocene conglomerate exposed in the Chuitna-Beluga rivers area on the west coast of Cook Inlet to identify the relative proportions of different source terranes that contributed sediment to the basin. Compositional data were collected by counting all the pebble- and cobble-sized 
clasts in a predefined area on an outcrop face until at least 100 clasts were counted. A total of nine clast counts were conducted at five different locations. Four clast counts from conglomerate beds mapped as West Foreland Formation (Detterman and others, 1976; Magoon and others, 1976) were completed just south of the Capps Glacier (W1-W4 on fig. 2). Conglomeratic units exposed on the Theodore River and mapped variously as Hemlock Conglomerate (Detterman and others, 1976) or West Foreland Formation (Detterman and others, 1976) were the site of three clast counts shown as H1-H3 on figure 2. The last two clast counts were conducted in the Tyonek Formation (Detterman and others, 1976; Magoon and others, 1976) along the Lewis River (T1-T2 on fig. 2).

Qualitative descriptions of clasts were made in the field. Samples of each clast type were collected so that thin sections could be made to check the field identifications. Fifty-two clast compositions were grouped into eight categories: extrusive volcanic, plutonic, volcaniclastic sandstone, greenstone, quartz, chert, sedimentary, and metasedimentary types. Pie-chart graphs in figure 10 showing the distribution of these categories in each clast count indicate several trends.

All clast counts in the West Foreland Formation (W1-W4 on fig. 10) contain an abundant amount of extrusive volcanic clasts (79-87 percent) and relatively high amounts of plutonic clasts (12-15 percent). Small amounts of greenstone ( $<6$ percent) and volcaniclastic clasts ( $<1$ percent) were also present. These percentages are quite different from those seen in the conglomerate along the Theodore River (H1-H4 on fig. 10). There, the most copious clast type is quartz (33-49 percent), with extrusive volcanic types running a close second but at a much smaller fraction than the West Foreland conglomerate (33-35 percent). Chert composes 11-21 percent of the clasts on the Theodore River, sedimentary types about 3-10 percent, and finally smaller proportions ( $<2$ percent) of metasedimentary and plutonic clasts. The Tyonek Formation clast counts also show distinct compositional trends (T1 and T2 on fig. 10). Metasedimentary and extrusive types are the most prolific, composing 20-30 percent and 13-41 percent of the total counts, respectively. Lesser clast types include in descending order: quartz (8-23 percent), sedimentary (9-20 percent), chert (12-16 percent), and plutonic (0-8 percent).

Previous studies have different interpretations for the stratigraphic position of exposures along the Theodore River. Magoon and others (1976) mapped those units, as well as the strata exposed on the Lewis and Beluga rivers northwest of the Lake Clark fault, as West Foreland Formation, presumably based upon their on-strike relationship with other conglomeratic sections identified as West Foreland Formation by dating of plant fossils. Detterman and others (1976) identified the Theodore River strata as Hemlock Conglomerate. Clast compositions outlined in Calderwood and Fackler (1972) for the subsurface type sections of both the West Foreland Formation and Hemlock Conglomerate indicate some dissimilarity between the two units. The clasts in the West Foreland Formation are described as, "green pebbles with a probable volcanic origin" (p. 742), whereas the clasts in the Hemlock Conglomerate are "chert, quartz, quartzite, igneous rocks and metasediments" (p. 745). Average sandstone modal compositions for the West Foreland Formation are $\mathrm{Q}_{22} \mathrm{~F}_{27} \mathrm{~L}_{51}$ (Stewart, 1976), $\mathrm{Q}_{23} \mathrm{~F}_{30} \mathrm{~L}_{47}$ (Schluger, 1977; Kuryvial, 1977), and $Q_{29} F_{22} L_{49}$ (Lankford and Magoon, 1978), with the lithics being primarily volcanic. Magoon and Egbert (1986) indicate the average modal sandstone composition in the Hemlock conglomerate for outcrop exposures and subsurface samples is $\mathrm{Q}_{66} \mathrm{~F}_{15} \mathrm{~L}_{19}$, and that the sandstone is generally feldspatholithic to lithofeldspathic. They state that the volcaniclithic to total lithic ratio is low (0.21) in the Hemlock Conglomerate, and that most lithic fragments are plutonic and metamorphic. Therefore, comparing the qualitative descriptions with our clast count data, it would be plausible that the exposures that Detterman and others (1976) mapped along the Theodore River are indeed Hemlock Conglomerate. This is a new and important idea because the Hemlock Conglomerate is the primary oil-bearing unit in the basin, and due to lack of outcrop exposure, very little is know about its geometry and provenance. Our hypothesis can be tested if proven Hemlock core can be accessed and additional clast counts done on subsurface and outcrop strata.

\section{SUMMARY}

This study is important because it will provide a better understanding of the stratigraphic framework and development of Cook Inlet forearc basin. An improved understanding of structural and stratigraphic relationships can be used to examine the timing and style of fault development along the basin margins. We plan to address questions such as: (1) Did the various fault systems propagate basinward, similar to thrust belt-foreland basin systems?, (2) Was sediment input in the basin dominated by proximal sources distributed by margin perpendicular river systems, or was sediment predominantly carried to the basin from distal sources by the axial fluvial system? and (3) What can the geographic and temporal distribution of provenance tell us about the geodynamics of basin development, such as where the subsidence was concentrated and what was controlling it? A better understanding of the Cenozoic tectonic controls will facilitate more accurate and detailed depositional models for Cook Inlet basin. 


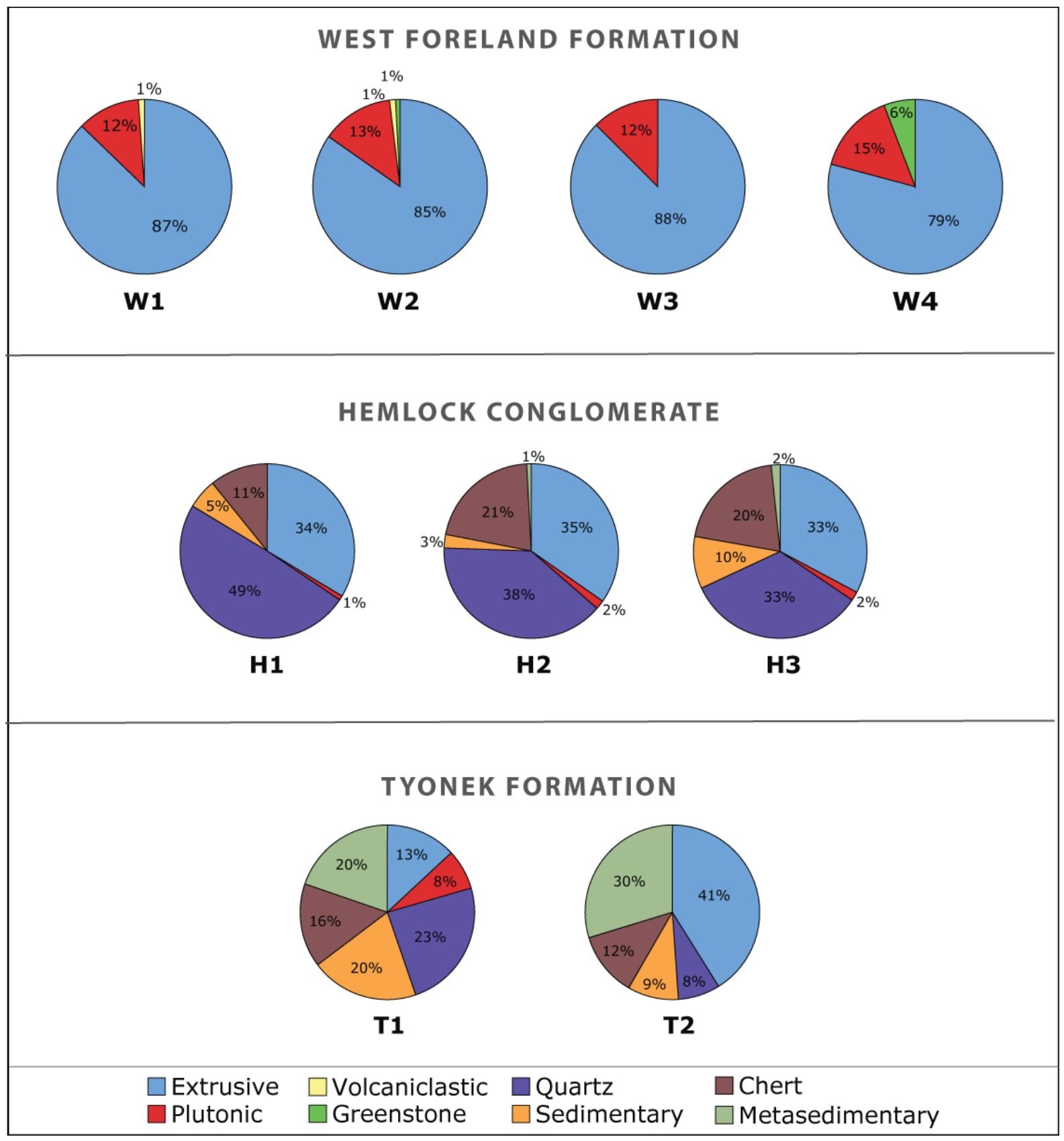

Figure 10. Conglomerate clast compositions from the Hemlock, West Foreland, and Tyonek formations from clast counts conducted on outcrops. See text for discussion. 


\section{ACKNOWLEDGMENTS}

Field operations for the August 2007 field season were funded by the Alaska Division of Geological \& Geophysical Surveys operating budget, Purdue University, Benchmark Oil and Gas, Chevron Midcontinent/Alaska, and Pioneer Natural Resources.

\section{REFERENCES}

Adkison, W.L., Kelley, J.S., and Newman, K.R., 1975, Lithology and palynology of Tertiary rocks exposed near Capps Glacier and along Chuitna River, Tyonek Quadrangle, southern Alaska, U.S. Geological Survey Publication Series OF 75-21, 58 p., 1 sheet.

Barnes, F.F., 1966, Geology and coal resources of the Beluga-Yentna region, Alaska: U.S. Geological Survey Bulletin 1202-C, p. 1-54, 4 sheets.

Barnes, F.F., and Payne, T.G., 1956, The Wishbone Hill district, Matanuska coal field, Alaska: U.S. Geological Survey Bulletin 1016, 88 p.

Bruhn, R.L., and Haeussler, P.J., 2006, Deformation driven by subduction and microplate collision: Geodynamics of Cook Inlet basin, Alaska: Geological Society of America Bulletin, v. 118, no 3/4, p. 289-303.

Bullen, M.E., Burbank, D.W., Abdrakhmatov, K.Y., and Garver, J., 2001, Late Cenozoic tectonic evolution of the northwestern Tien Shan-Constraints from magnetostratigraphy, detrital fission track, and basin analysis: Geological Society of America Bulletin, v. 113, no. 12, p. 1,544-1,559.

Calderwood, K.W., and Fackler, W.C., 1972, Proposed stratigraphic nomenclature for Kenai Group, Cook Inlet basin, Alaska: American Association of Petroleum Geologists Bulletin, v. 56, p. 739-754.

Detterman, R.L., and Hartsock, J.K., 1966, Geology of the Iniskin-Tuxedni region, Alaska: U.S. Geological Survey Professional Paper 512, 78 p., 6 sheets.

Detterman, R.L., and Reed, B.L., 1980, Stratigraphy, structure, and economic geology of the Iliamna quadrangle, Alaska: U.S. Geological Survey Bulletin 1368-B, p. B1-B86, 1 sheet.

Detterman, R.L., Hudson, T., Plafker, G., Tysdal, R.G., and Hoare, J.M., 1976, Reconnaissance geologic map along Bruin Bay and Lake Clark faults in Kenai and Tyonek quadrangles, Alaska: U.S. Geological Survey Open File Map 76-477, 4 p., scale 1:250,000.

Detterman, R.L., Case, J.E., Miller, J.W., Wilson, F.H., and Yount, M.E., 1996, Stratigraphic framework of the Alaska Peninsula: U.S. Geological Survey Bulletin 1969-A, 74 p.

Dickinson, W.R., 1995, Forearc basins in Busby, C.J., and Ingersoll, R.V., eds., Tectonics of Sedimentary Basins: Cambridge, MA, Blackwell Science, p. 221-262.

Dickinson, W.R., and Suczek, C.A., 1979, Plate tectonics and sandstone compositions: American Association of Petroleum Geologists Bulletin, v. 63, no. 12, p. 2,164-2,182.

Dickinson, W.R., Harbaugh, D.W., Saller, A.H., Heller, P.L., and Snyder, W.S., 1983, Detrital modes of upper Paleozoic sandstones derived from the Antler orogen in Nevada-Implications for the nature of the Antler orogeny: American Journal of Science, v. 282, p. 481-509.

Ehlers, T.A., Willett, S.D., Armstrong, P.A., and Chapman, D.S., 2003, Exhumation of the Central Wasatch Mountains, Utah; 2. Thermo-kinematics of exhumation, erosion and thermochronometer interpretation: Journal of Geophysical Research, v. 108, p. 2,173.

Farley, K.A., 2000, Helium diffusion from apatite I-General behavior as illustrated by Durango fluorapatite: Journal of Geophysical Research, v. 105, p. 2,903-2,914.

Fildani, A., and Hessler, A.M., 2005, Stratigraphic record across a retroarc basin inversion-Rocas VerdesMagallanes Basin, Patagonian Andes, Chile: Geological Society of America Bulletin, v. 117, no. 11-12, p. 1,596-1,614.

Fitzgerald, P.G., Sorkhabi, R.B., Redfield, T.F., and Stump, E., 1995, Uplift and denudation of the Alaska Range-A case study in the use of apatite fission track thermochronology to determine absolute uplift parameters: Journal of Geophysical Research, v. 100, p. 20,175-20,191.

Flores, R.M., Stricker, G.D., and Kinney, S.A., 2004, Alaska coal geology, resources, and coalbed methane potential: U.S. Geological Survey DDS-77, 125 p., 3 sheets.

Fuchs, W.A., 1980, Tertiary tectonic history of the Castle Mountain-Caribou fault system in the Talkeetna Mountains, Alaska: Salt Lake City, University of Utah, Ph.D. dissertation, 150 p. 
Gillis, R.J., LePain, D.L., Finzel, E.S., Ridgway, K.D., 2009, Preliminary observations of the Capps Glacier fault and its potential as a regional-scale Tertiary structure along the western and northern margin of Cook Inlet basin: Alaska Division of Geological \& Geophysical Surveys Preliminary Interpretive Report, in press.

Gillis, R.J., Reifenstuhl, R.R., Decker, P.L., 2008, Implications of new fission-track thermochronology for Mesozoic and Tertiary basin margin exhumation, upper Alaska Peninsula (abs.): Proceedings, 11th international Conference on Thermochronometry, Anchorage, Alaska, September 15th-19th, 2008.

Gillis, R.J., Horton, B.K., Grove, M., 2006, Thermochronology, geochronology, and upper crustal structure of the Cordillera Real-Implications for Cenozoic exhumation of the central Andean plateau: Tectonics, v. 25, no. 6, doi: 10.1029/2005TC001887.

Grantz, Arthur, 1966, Strike-slip faults in Alaska: U.S. Geological Survey Open-File Report 66-53, 82 p.

Guest, B., Stockli, D., Grove, M., Axen, G., Lam, P., and Hassanzadeh, J., 2006, Thermal histories from the central Alborz Mountains, northern Iran-Implications for the spatial and temporal distribution of deformation in northern Iran: Geological Society of America Bulletin, v. 118, p. 1,507-1,521.

Haeussler, P.J., and Saltus, R.W., 2005, Twenty-six kilometers of offset since late Eocene time on the Lake Clark fault, in Haeussler, P.J., and Galloway, J., eds., Studies by the U.S. Geological Survey in Alaska, 2004: U.S. Geological Survey Professional Paper 1709-A, p. 1-4.

Haeussler, P.J., Bruhn, R.L., and Pratt, T.L., 2000, Potential seismic hazards and tectonics of the upper Cook Inlet basin, Alaska, based on analysis of Pliocene and younger deformation: Geological Society of America Bulletin, v. 112, no. 9, p. 1,414-1,429.

Hayes, J.B., Harms, J.C., and Wilson, T., Jr., 1976, Contrasts between braided and meandering stream deposits, Beluga and Sterling Formations (Tertiary), Cook Inlet, Alaska, in Miller, T.P., ed., Recent and ancient sedimentary environments in Alaska: Proceedings, Alaska Geological Society Symposium, April 2-4, 1975, Anchorage, Alaska Geological Society, p. J1-J27.

Hickey, J.J., Wilson, M.D., and Reifenstuhl, R.R., 2007, Petrographic study of 50 samples from the Tertiary sandstone of Cook Inlet, Alaska_-Potential tight gas reservoirs: Alaska Division of Geological \& Geophysical Surveys Report of Investigation 2007-2, 64 p.

Hite, D.M., 1976, Some sedimentary aspects of the Kenai Group, Cook Inlet, Alaska, in Miller, T.P., ed., Recent and ancient sedimentary environments in Alaska: Proceedings, Alaska Geological Society Symposium, April 2-4, 1975, Anchorage, Alaska Geological Society, p. I1-I23.

Ingersoll, R.V., and Suczek, C.A., 1979, Petrology and provenance of Neogene sand from Nicobar and Bengal fans, DSDP sites 211 and 218: Journal of Sedimentary Petrology, v. 49, p. 1,217-1,228.

Ivanhoe, L.F., 1962, Right-lateral strike-slip movement along the Lake Clark fault, Alaska: Geological Society of America Bulletin, v. 73, no. 9, p. 911-912.

Ketcham, R.A., Donelick, R.A., and Donelick, M.B., 2000, AFTSolve: A program for multi-kinetic modeling of apatite fission-track data: Geological Materials Research, v. 2, p. 1-32.

Kirby, Eric, Reiners, P.W., Krol, M.A., Whipple, K.X., Hodges, K.V., Farley, K.A., Tang, W., and Chen, Z., 2002, Late Cenozoic evolution of the eastern margin of the Tibetan Plateau—Inferences from ${ }^{40} \mathrm{Ar} /{ }^{39} \mathrm{Ar}$ and $(\mathrm{U}-\mathrm{Th}) / \mathrm{He}$ thermochronology: Tectonics, v. 21, no. 1, 20 p.

Kirschner, C.E., 1988, Map showing sedimentary basins of onshore and continental shelf areas, Alaska: U.S. Geological Survey Miscellaneous Investigations Series Map 1-1873, scale 1:2,500,000.

Kuryvial, R.J., 1977, Diagenetic alteration of sandstones from lower Cook Inlet COST No. 1: Cities Service Company, 10 p.

Kusky, T.M., Bradley, D.C., Haeussler, P.J., and Karl, S., 1997, Controls on accretion of flysch and mélange belts at convergent margins_Evidence from the Chugach Bay thrust and Icework mélange, Chugach accretionary wedge, Alaska: Tectonics, v. 16, no. 6, p. 855-878.

Lankford, S.M., and Magoon, L.B., 1978, Petrography of the Upper Jurassic through Oligocene sandstones in the Cape Douglas-Kamishak Hills area, lower Cook Inlet, in Johnson, K.M., ed., The United States Geological Survey in Alaska: Accomplishments during 1977: U.S. Geological Survey Circular 772-B, p. B60-B62.

Lovera, O.M., Richter, F.M., and Harrison, T.M., 1989, The ${ }^{40} \mathrm{Ar} /{ }^{39} \mathrm{Ar}$ thermochronometry for slowly cooled samples having a distribution of diffusion domain sizes: Journal of Geophysical Research, v. 94, p. 17,917-17,935.

Magoon, L.B., Adkison, W.L., and Egbert, R.M., 1976, Map showing geology, wildcat wells, Tertiary plant fossil localities, K-Ar age dates, and petroleum operations, Cook Inlet area, Alaska: U.S. Geological Survey Miscellaneous Investigations Series Map I-1019, scale 1:250,000. 
Magoon, L.B., and Egbert, R.M., 1986, Framework geology and composition, in, Magoon, L.B., ed., Geologic studies of the Lower Cook Inlet COST No. 1 well, Alaska Outer Continental Shelf: U.S. Geological Survey Bulletin 1596, p. 65-90.

McLennan, S.M., Hemming, S., McDaniel, D.K., and Hanson, G.N., 1993, Geochemical approaches to sedimentation, provenance and tectonics, in Johnsson, M.J., and Basu, A., eds., Processes controlling the composition of clastic sediments: Geological Society of America Special Paper 284, p. 21-40.

Plafker, G., and Berg, H.C., eds., 1994, The Geology of Alaska: Geological Society of America, The Geology of North America, v. G-1.

Plafker, G., Detterman, R.L., and Hudson, T., 1975, New data on the displacement history of the Lake Clark fault, in Yount, M.E., ed., U.S. Geological Survey Alaska Program, 1975: U.S. Geological Survey Circular 722, p. 44-45.

Plafker, G., Moore, J.C., and Winkler, G.R., 1994, Geology of the southern Alaska margin, in Plafker, G., and Berg, H.C., eds., The Geology of Alaska: Geological Society of America, The Geology of North America, v. G-1, p. 389-449.

Potter, P.E., Maynard, J.B., and Depetris, P.J., 2005, Muds and mudstones—-Introduction and overview: New York, Springer-Verlag, 297 p.

Rawlinson, S.E., 1984, Environments of deposition, paleocurrents, and provenance of Tertiary deposits along Kachemak Bay, Kenai Peninsula, Alaska: Sedimentary geology, v. 38, p. 421-442.

Reed, B.L., and Lanphere, M.A., 1969, Age and geochemistry of Mesozoic and Tertiary plutonic rocks in southcentral Alaska, Geological Society of America Bulletin, v. 80, p. 23-44.

Reiners, P.W., and Brandon, M.T., 2006, Using thermochronology to understand orogenic erosion: Annual Review of Earth and Planetary Sciences, v. 34, p. 419-466.

Schluger, P.R., 1977, Petrographic summaries of sidewall cores from 1,810-4,560 feet-Core 1 and core 2, Atlantic Richfield lower Cook Inlet COST No. 1: Mobil Oil Corporation, 10 p.

Schmoll, H.R., and Yehle, L.A., 1987, Surficial geologic map of the northwestern quarter of the Tyonek A-4 quadrangle, south-central Alaska: U.S. Geological Survey Miscellaneous Field Studies Map MF-1934, scale 1:31,680.

Spotila, J.A., Niemi, Nathan, Brady, Robert, House, Martha, Buscher, Jamie, and Oskin, Mike, 2007, Long-term continental deformation associated with transpressive plate motion-The San Andreas fault: Geology, v. 35; no. 11; p. 967-970.

Stewart, R.J., 1976, Turbidites of the Aleutian abyssal plain-Mineralogy, provenance, and constraints for Cenozoic motion of the Pacific Plate: Geological Society of America Bulletin, v. 87, no. 5, p. 793-808.

Swenson, R.F., 1997, Introduction to Tertiary tectonics and sedimentation in the Cook Inlet Basin, in Karl, S.M., Vaughn, N.R., and Ryherd, T.J., eds., 1997 Guide to the geology of the Kenai Peninsula, Alaska: Anchorage, Alaska Geological Society, p. 18-27.

Trop, J.M., Szuch, D.A., Rioux, M., and Blodgett, R.B., 2005, Sedimentology and provenance of the Upper Jurassic Naknek Formation, Talkeetna Mountains, Alaska-Bearings on the accretionary tectonic history of the Wrangellia composite terrane: Geological Society of America Bulletin, v. 117, no. 5/6, p. 570-588.

Willis, J.B., Haeussler, P.J., Bruhn, R.L., and Willis, G.C., 2007, Holocene slip rate for the western segment of the Castle Mountain Fault, Alaska: Bulletin of the Seismological Society of America, v. 97, no. 3, p. 1,0191,024 .

Wolfe, J.A., Hopkins, D.M., and Leopold, E.B., 1966, Tertiary stratigraphy and paleobotany of the Cook Inlet region, Alaska: U.S. Geological Survey Publication Series P398-A, 1 sheet, p. A1-A29. 